\title{
Repercussões da Experiência como Palhaço de Hospital em Profissionais da Saúde Recém-Formados - Relato de Experiências
}

\author{
Martins, Mauro Fantini Nogueira; Arnaut, Amanda de Moura; Cillo, Bianca \\ Bongiorno de; Chaves, Guilherme Souza \\ Centro Universitário São Camilo — maurofantini@gmail.com
}

\begin{abstract}
INTRODUÇÃO: em 2010 foi iniciado o projeto de extensão Narizes de Plantão em um centro universitário particular da cidade de São Paulo. Nesse projeto, graduandos da área da saúde de variados cursos (Biomedicina, Enfermagem, Fisioterapia, Medicina, Nutrição e Psicologia) treinam intensamente a linguagem teatral do clown e a utilizam em visitas periódicas a hospitais. a linguagem do clown aborda constantemente habilidades de improvisação, brincadeira, espontaneidade e sinceridade e demanda do estudante reflexão e treino a respeito de sua escuta, do seu trabalho em equipe e do seu olhar para colegas e pacientes. É possível que tal treinamento influencie a prática profissional do aluno no mercado de trabalho. OBJETIVOS: verificar se os conceitos artísticos e relacionais treinados durante a participação no projeto de extensão Narizes de Plantão influenciam a prática profissional em saúde de ex-alunos formados e empregados. MÉTODOS: Dez exparticipantes dos Narizes de Plantão, com diferentes formações, foram entrevistados sobre as possíveis influências da linguagem do clown em suas atividades profissionais. As respostas foram coletadas e analisadas individual e conjuntamente, em busca de temáticas similares. RESULTADOS: Duas fisioterapeutas ex-participantes dos Narizes de Plantão relataram utilizar abordagens lúdicas improvisadas para ganhar a confiança de pacientes e a participação deles em exercícios monótonos de reabilitação física. uma médica contou que após deixar a faculdade, entrou em uma Organização Não-Governamental de palhaços em hospital e criou um blog, onde publica suas histórias de médica-palhaça ou palhaça-médica. uma terapeuta ocupacional disse que uma característica marcante do palhaço utilizada diariamente em seu trabalho é a de comemorar as pequenas vitórias. Segundo ela, isso dá mais confiança a pacientes e familiares para seguir um tratamento. CONCLUSÕES: para alguns profissionais, passar por uma atividade artística durante a graduação gerou influências positivas em suas práticas de atendimento. É possível, portanto, que ferramentas relacionais da linguagem do clown sejam incorporadas ao cotidiano do profissional de saúde.
\end{abstract}

Martins, Mauro Fantini Nogueira; Arnaut, Amanda de Moura; Cillo, Bianca Bongiorno de; Chaves, Guilherme Souza. Repercussões da Experiência como Palhaço de Hospital em Profissionais da Saúde RecémFormados - Relato de Experiências. In: Anais do Congresso Internacional de Humanidades \& Humanização em Saúde [= Blucher Medical Proceedings, num.2, vol.1]. São Paulo: Editora Blucher, 2014. ISSN 2357-7282

DOI 10.5151/medpro-cihhs-10761 